\title{
Contribution to the Stratigraphy of the Onshore Paraíba Basin, Brazil
}

\author{
DILCE F. ROSSETTI ${ }^{1}$, ANA M. GÓES ${ }^{2}$, FRANCISCO H.R. BEZERRA ${ }^{3}$, MÁRCIO M. VALERIANO ${ }^{1}$, \\ BENJAMIM B. BRITO-NEVES ${ }^{2}$ and FELIPE L. OCHOA ${ }^{2}$ \\ ${ }^{1}$ Instituto Nacional de Pesquisas Espaciais (INPE), Divisão de Sensoriamento Remoto, \\ Av. dos Astronautas, 1758, 12245-910 São José dos Campos, SP, Brasil \\ ${ }^{2}$ Universidade de São Paulo (USP), Instituto de Geociências, Rua do Lago, 562, 05508-080 São Paulo, SP, Brasil \\ ${ }^{3}$ Universidade Federal do Rio Grande do Norte (UFRN), Departamento de Geologia, Centro de Ciências Exatas e da Terra, \\ Campus Universitário, s/n, Bairro de Lagoa Nova, 59078-970 Natal, RN, Brasil
}

Manuscript received on August 28, 2010; accepted for publication on April 20, 2011

\begin{abstract}
Several publications have contributed to improve the stratigraphy of the Paraíba Basin in northeastern Brazil. However, the characterization and distribution of sedimentary units in onshore areas of this basin are still incomplete, despite their significance for reconstructing the tectono-sedimentary evolution of the South American passive margin. This work provides new information to differentiate among lithologically similar strata, otherwise entirely unrelated in time. This approach included morphological, sedimentological and stratigraphic descriptions based on surface and sub-surface data integrated with remote sensing, optically stimulated luminescence dating, $\mathrm{U}+\mathrm{Th} / \mathrm{He}$ dating of weathered goethite, and heavy mineral analysis. Based on this study, it was possible to show that Cretaceous units are constrained to the eastern part of the onshore Paraíba Basin. Except for a few outcrops of carbonatic rocks nearby the modern coastline, deposits of this age are not exposed to the surface in the study area. Instead, the sedimentary cover throughout the basin is constituted by mineralogically and chronologically distinctive deposits, inserted in the Barreiras Formation and mostly in the Post-Barreiras Sediments, of early/middle Miocene and Late Pleistocene-Holocene ages, respectively. The data presented in this work support tectonic deformation as a factor of great relevance to the distribution of the sedimentary units of the Paraíba Basin.
\end{abstract}

Key words: morphology, sedimentology, stratigraphy, chronology, tectonics, Paraíba Basin.

\section{INTRODUCTION}

The Paraíba Basin, situated in northeastern Brazil, consists of a structure bounded by the Pernambuco Lineament near the city of Recife, and the Mamanguape Fault, to the north of the city of João Pessoa (Fig. 1). Several previous publications,

Correspondence to: Dilce de Fátima Rossetti

E-mail: rossetti@dsr.inpe.br including surface and subsurface information, have significantly contributed to the knowledge of the sedimentary fill of this basin (e.g., Barbosa et al. 2003, Barbosa and Lima Filho 2006, Córdoba et al. 2008, Brito Neves et al. 2009). The analysis of these works indicates that sediment deposition was initiated in the Coniacian-Santonian, with the origin of siliciclastic rocks of the Beberibe Formation during sea level lowstand to early transgression 
(e.g., Córdoba et al. 2008). This event continued up to the end of the Campanian, giving rise to the Itamaracá Formation. The transgressive peak was marked by phosphate deposition at the end of the Campanian, followed by deposition of carbonatic rocks of the Gramame Formation during sea level highstand. In the Tertiary, N/NNE extension and W/ WNW compression associated with South American intraplate stresses (Córdoba et al. 2008) accompanied an overall regressive phase, which resulted in the deposition of Paleogene carbonatic rocks of the Maria Farinha Formation (Beurlen 1967a, b) and siliciclastic rocks of the Barreiras Formation, the latter regarded as formed in an undetermined time either after the latest Miocene (Córdoba et al. 2008) or after the Pliocene (Barbosa et al. 2003).

Despite the above presented summary of the sedimentary evolution, there are many questions that remain unresolved concerning the stratigraphic framework of the Paraíba Basin. For instance, most of the sedimentary units were defined based on general lithological descriptions derived from sub-surface data and/or a few surface information, which do not allow an easy differentiation for mapping purposes. In addition, the stratigraphic schemes have been chiefly based on data from offshore areas, and in general there is an overall lack of information regarding the characterization and distribution of the sedimentary units along onshore areas. A large effort is still required to integrate subsurface and surface information in order to analyze the stratigraphic evolution in onshore areas of the Paraíba Basin within the context of tectonic deformation. Most of the sedimentary deposits exposed along this basin have been included under the lithostratigraphic term Barreiras Formation. Further investigation is required to differentiate this unit from overlying Quaternary strata that, though thin, similarly might have a significant geographic distribution. Finally, additional efforts are required to introduce new criteria for the distinction among these strata and older siliciclastic units, such as the
Beberibe Formation, particularly in the absence of intervening carbonatic units that could be used as stratigraphic markers.

The present work integrates subsurface and surface data from the onshore Paraíba Basin (Fig. 1), aiming to provide a more complete insight on the spatial distribution of the stratigraphic units that form its sedimentary pile. The main emphasis is placed on the presentation of morphological and sedimentological descriptions that might assist to differentiate among lithologically similar strata otherwise entirely unrelated in time, comprising siliciclastic strata of Cretaceous, Neogene and Quaternary ages. Although a detailed approach on the tectonic framework is beyond the scope of this study, the stratigraphic information presented herein allows a preliminary discussion on the factors that have controlled the distribution of the sedimentary units in this basin. The new data provided herein are of relevance in studies aiming to approach the tectono-sedimentary evolution of the South American passive margin.

\section{GEOLOGICAL FRAMEWORK}

The Paraíba Basin developed over crystalline rocks (mostly ortognaisses, migmatites and highly metamorphosed supracrustal rocks) of the Borborema Province, which corresponds to the central part of an orogenic belt formed during the Pan-African/Brazilian Orogeny circa $600 \mathrm{Ma}$ (Brito Neves et al. 2000). This province is dominated by continental-scale, mainly E-W trending shear zones. These were reactivated during the late Jurassic to early Cretaceous rifting, when many structures acted as major boundaries for the Brazilian marginal basins (e.g., Matos 1992, Castro et al. 2008), with the Paraíba Basin being one of them. Several shear zones were reactivated again in the late Cretaceous and Cenozoic, deforming the postrift sedimentary units (e.g., Nóbrega et al. 2005), a process that seems to have been active at least until 
the Quaternary (Bezerra et al. 2008, Nogueira et al. 2010). Further evidence that this region remained active after the Cretaceous rifting is provided by records of early and late Neogene (Saadi and Torquato 1992) and Quaternary (Bezerra et al. 2005) seismites and Late Pleistocene faults, as well as by an abundance of tectonic lineaments (Furrier et al. 2006). In particular, faults with vertical offsets as high as $260 \mathrm{~m}$ have disturbed flat-lying deposits and tablelands since the Miocene (Bezerra et al. 2001). Instrumental and historical data further support that the Paraíba Basin is located in one of the most seismically active areas in intraplate South America (e.g., Bezerra et al. 2007, Ferreira et al. 1998, 2008). Many NE-SW, E-W and NW-SE trending faults that have affected the sedimentary pile of the Paraíba Basin might be a reflex of these reactivations (Brito Neves et al. 2000).

Three main depocenters have been proposed for the Paraíba Basin (Fig. 1), included in the Olinda (south), Alhandra (central) and Miriri (north) SubBasins (Barbosa et al. 2003). The sedimentary fill (Fig. 2) starts with the Beberibe Formation (Coniacian to Campanian), a 360 m-thick unit consisting of medium- to coarse-grained sandstones and conglomerates of continental, chiefly fluvial, origin. As it will be shown in this work, most of this unit is known from subsurface data. A few exposures

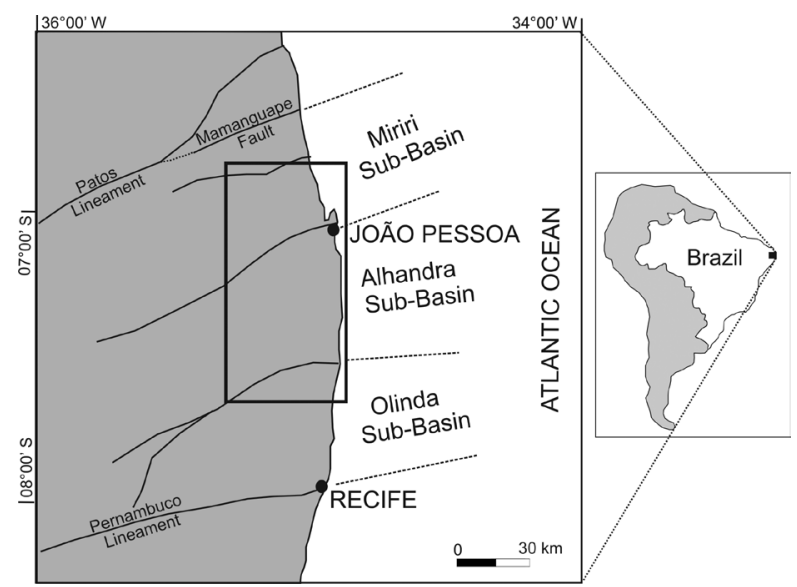

Figure 1: Location map of the Paraíba Basin in northeastern Brazil, with indication of its sub-basins.

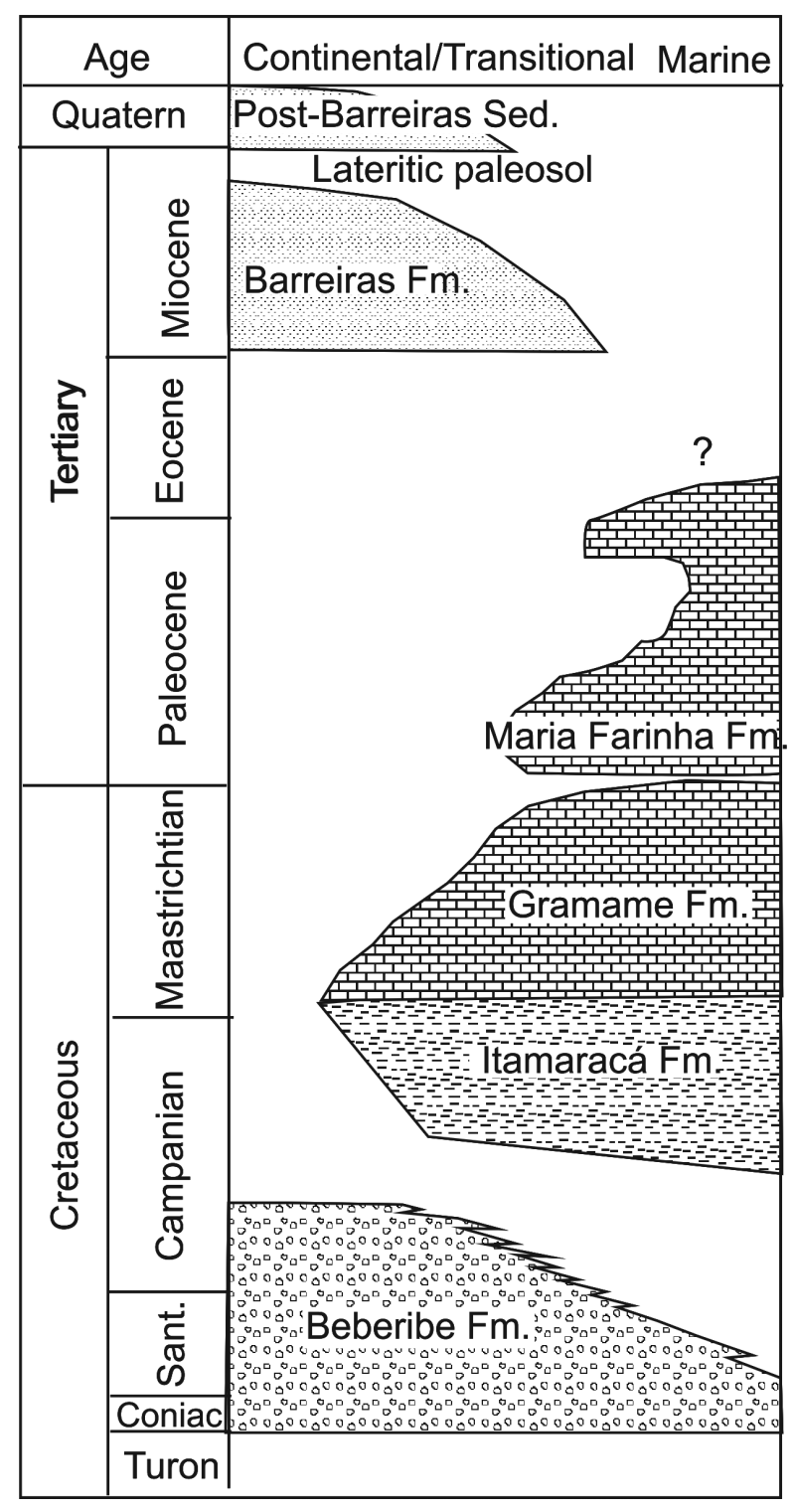

Figure 2: Simplified stratigraphic chart of the Paraíba Basin (modified from Barbosa et al. 2003).

of Santonian deposits related to this unit (Beurlen 1967a, b) were included in the Itamaracá Formation (Barbosa et al. 2003). Despite that the bulk of the Beberibe Formation occurs in subsurface, there are works (e.g., Beurlen 1967a, Brito Neves et al. 2009) proposing that these deposits are exposed along a widespread area throughout the Paraíba Basin. As discussed in a proper section, the most probable is that this interpretation results from the lack of criteria to differentiate this unit from 
endured seismites (cf. Rossetti et al. 2011) formed on the top of the Barreiras Formation. Therefore, the stratigraphic position of these deposits will be reviewed in the light of new stratigraphic and sedimentological data presented herein.

The Itamaracá Formation comprises an up to 70 m-thick Santonian-Campanian unit of richly fossiliferous and calciferous sandstones and muddy siltstones deposited in marine transitional settings. These deposits, topped by an up to 2 m-thick phosphate layer that extends throughout the Paraíba Basin, were temporarily included in the overlying Gramame Formation (Beurlen, 1967a, b). Similar to the exposures of the Beberibe Formation, the ones of the Itamaracá Formation are also rare, which makes the characterization of facies variability difficult, so far defined mostly with the basis on core data.

The Paraíba Basin was undergone to an extensive phase of carbonate sedimentation from the end of the Campanian to the end of the Maastrichtian, mostly forming wackestones and mudstones over shallow shelf environments recorded by the Gramame Formation (I.M. Tinoco, unpublished data). This unit, richly fossiliferous, is exposed at the margin of the Gramame River and in several quarries in the adjacency of João Pessoa and the town of Alhandra. This unit, together with the Beberibe and Itamaracá Formations, has been included as part of the Neoturonian to middle Campanian K88-K130 depositional sequence (cf. Córdoba et al. 2008) associated with the rift phase of the basin. However, these authors have also stated that, rather than representing temporally unrelated deposits, the sedimentary units formed at the base of the Paraíba Basin, including the Beberibe, Itamaracá and Gramame Formations, might be most likely laterally intergrading.

The post-Cretaceous depositional history of the Paraíba Basin that developed during drifting is even less detailed. This is recorded by the Paleogene (possibly Danian-Eocene? I.M. Tinoco, unpublished data) Maria Farinha Formation (Beurlen 1967a, b). This unit consists of calcareous rocks lithologically similar to the Gramame Formation, and fossiliferous (reefal) dolomitic limestone. In addition to the younger age indicated by fossil content, this unit is distinguished from the Maastrichtian Gramame Formation with the basis on the high volume of terrigenous components within carbonates. Only a few exposures of the Maria Farinha Formation from the southern portion of the basin are available (Barbosa et al. 2003), either because this area had a preferential deposition or because it was protected from erosion.

A nearly 70 m-thick siliciclastic succession consisting of sandstones and mudstones of the Barreiras Formation related to an uncertain Neogene age overlies the Cretaceous units (e.g., Beurlen 1967a). This age was also stated for this unit exposed in northern Brazil (Arai et al. 1988, Leite et al. 1997a, b, Arai 2006). The Barreiras Formation, traditionally attributed to fluvial and alluvial fan systems (p.e., Beurlen 1967a, Bigarella 1975, Mabesoone et al. 1972), has been reinterpreted as encompassing marine influenced deposits in many other areas of northern and northeastern Brazil (Alheiros and Lima Filho 1991, Rossetti and Góes 2009, Rossetti and Dominguez in press). The lack of detailed sedimentological and stratigraphic descriptions has resulted in the inclusion of a high volume of Quaternary deposits in this unit.

\section{MATERIALS AND METHODS}

This investigation is based on field and subsurface information integrated with remote sensing analysis. Field data are derived from detailed facies and stratigraphic information from exposures consisting of road cuts, coastal cliffs and quarries distributed along onshore areas of the Paraíba Basin. Facies descriptions included parameters as color, lithology, texture and primary sedimentary structures. The sedimentary 
facies were photographed and recorded on measured lithostratigraphic profiles. These data were integrated with subsurface lithological information derived from drills for water prospection. Despite the large volume of drills available for this study ( $\sim 900$ drills), only 19 showed lithological information meaningful for helping stratigraphic correlations.

Geographic Positioning System (GPS) provided the location of the studied profiles and drills, which were plotted on digital elevation models derived from the Shuttle Radar Topography Mission (SRTM). This procedure furnished the basis to correlate the studied profiles and elaborate geological sections along selected transects. In addition, it helped to highlight the topographic and morphologic features useful for distinguishing among individual geological units. The integration of all these data helped the elaboration of the geological map. Original 90-m resolution (3 arc seconds) synthetic aperture $C(\lambda=6 \mathrm{~cm})$ band radar data, downloaded from the site http://edc.usgs. gov/srtm/data/obtainingdata.html, were used in this study. These data are unprojected, having geographic coordinates as reference units and WGS84 as reference ellipsoid and datum. Elevations are expressed in meters. The SRTM data were processed using customized shading schemes and palettes in the software Global Mapper. The development of such palettes was conducted through an interactive approach of frequent palette setting changes using display tools provided by this software.

In addition, the new stratigraphic information provided in this study was combined with data derived from laboratory studies including: Optically Stimulated Luminescence (OSL); heavy mineral assemblage; and (U+Th)/He dating of weathered goethite. The OSL analysis of quartz grains was performed using a blue light (470 nm) and detection through a $\sim 5 \mathrm{~mm}$ Hoya U-340 filter. The OSL ages were obtained using the standardized growth curve (SGC) method (Roberts and Duller 2004). However, in order to validate the equivalent dose $\left(D_{e}\right)$, a single aliquot regenerative dose (SAR) was also used in 15 random samples. For the SGC, the natural luminescence signal $\left(\mathrm{L}_{\mathrm{n}}\right)$ and the laboratory test dose $\left(T_{n}\right)$ were measured. The ratio of both signals $(\mathrm{Ln} /$ Tn) was multiplied by the size of the test dose applied $(\mathrm{Ln} / \mathrm{Tn} \times \mathrm{Td})$ to obtain the standardized OSL signal. In all cases, samples were preheated at $250^{\circ} \mathrm{C}$ for $10 \mathrm{~s}$ prior measurements and at $200^{\circ} \mathrm{C}$ for $10 \mathrm{~s}$ after the test dose. The same thermal treatments were used during the SAR protocol. Eight doses between 10 and 600 Gy were used to build the SGC, with five aliquots measured for each dose. To obtain the convenient De, a regression curve using the equation $\mathrm{I}(\mathrm{OSL})=$ $I_{\max }\left(1-\mathrm{e}^{-\mathrm{D} / \mathrm{Do}}\right)+\mathrm{k} . \mathrm{D}$ was fitted through the data.

Sample preparation for the heavy mineral analysis followed the standard procedures provided by Morton (1985) and Mange et al. (2003). Heavy minerals from grain sizes between $0.063-0.125 \mathrm{~mm}$ in all samples were separated to minimize the hydraulic effect and also because this fraction usually displays the highest volume of heavy minerals. A chemical treatment with oxalic acid ( $5 \%$ concentration) was applied to remove iron oxides and hydroxides from some samples. Heavy minerals were separated using bromoform (density 2.89), with the concentrates mounted on glass slides using natural balsam. Mineral counting under the petrographic microscope considered 100 grains of transparent (non-opaque) minerals, excluding micas, opaque grains and authigenic (authigenic anatase) minerals. The ZTR (zircon+tourmaline+rutile) and the unstable (epidote+amphibole)/stable(ZTR) were calculated after the independent counting of 100 transparent grains. In addition, $\mathrm{R} / \mathrm{Z}$ values were determined to compare the heavy mineral concentration for the entire group, attempting to minimize the effect of possible hydraulic and diagenetic controls (Morton and Hallsworth 1994).

The $(\mathrm{U}+\mathrm{Th}) / \mathrm{He}$ dating aimed to establish the time of formation of goethites from lateritic paleosols, which are widespread in the study area. The analyses were undertaken at the University of Queensland following the procedures described 
in Shuster et al. (2004, 2005). As a summary, this is based on measurements of $4 \mathrm{He},{ }^{238} \mathrm{U}$ and ${ }^{232} \mathrm{Th}$ using isotope-dilution mass spectrometry. Powder X-ray Diffractometry (XRD) and Scanning Electron Microscopy (SEM) were applied to identify the goethite phases. Selected samples with the purest goethite crystals were encapsulated in $\mathrm{Pt}$ foil packets and heated at $1150^{\circ} \mathrm{C}$ for He extraction. The Fe oxides were dissolved in $200 \mu \mathrm{L}$ of concentrated $\mathrm{HCl}$ and heated for 12 hours to $90{ }^{\circ} \mathrm{C}$. ${ }^{230} \mathrm{Th}$ and ${ }^{235} \mathrm{U}$ spikes were added during dissolution. Secular equilibrium among daughter nuclides in the ${ }^{238} \mathrm{U}$ series, a closed system for parents and daughters, and zero initial $4 \mathrm{He}$ at the time of precipitation were assumed for the $\mathrm{He}$ age calculations. To test for potential $4 \mathrm{He}$ losses, the samples were bombarded with $\sim 10^{14}$ protons $/ \mathrm{cm}^{2}$ using a $\sim 150 \mathrm{MeV}$ proton beam at the Harvard Cyclotron Laboratory to generate a uniform distribution of spallogenic $3 \mathrm{He}$.

\section{CHARACTERIZATION OF STRATIGRAPHIC UNITS}

Three transects, i.e., SW-NE, WSW-ESE and NNWESE (see I-I', II-II' and III-III' in Figs. 3 and 4A-C), based on the integration of outcrop and core information and a geological map (Fig. 5), provided insights into the spatial distribution of the sedimentary units in the Paraíba Basin. Due to their dominantly similar massive sandy nature, the Beberibe Formation and overlying strata could only be distinguished by integrating these data with morphological, mineralogical and chronological information. This approach provided criteria that allow to differentiate these strata in both surface and subsurface.

\section{BEBERIBE FORMATION}

This unit is represented only in subsurface, occurring along a belt that varies northward from nearly $15 \mathrm{~km}$ (transect III-III') to $30 \mathrm{~km}$ wide (transect I-I') from the modern coastline, decreasing in width northward of the Paraíba River. Its presence is confined to areas where the crystalline basement occurs several tens of meters to a few hundred meters down. This unit was analyzed in more detail in the drill P7 (see Fig. 3 for location), where massive and calciferous, mostly medium- to coarsegrained quartz-sandstones and conglomerates prevail, being locally interbedded with pelites. The analysis of heavy mineral assemblages from eight samples representative of this unit in this drill conspicuously revealed high volumes of garnet grains, with values ranging from $12 \%$ to $43 \%$ (mean of $24 \%$ ), a mineral that is remarkably either absent or only occasionally present as trace in other stratigraphic units of this basin (Tab. I). Another important mineralogical signature of the Beberibe Formation is the tourmaline content, which ranges from $6 \%$ to $19 \%$ (mean of $10 \%$ ). These are the lowest values recorded in the Paraíba Basin. Other heavy minerals in this unit are zircon (mean $=49 \%$ ), kyanite (mean $=9 \%$ ), rutile $($ mean $=4 \%)$ and, secondarily, staurolite, andalusite, topaz and amphibole (i.e., mean $<3 \%$ each). Other values are ZTR (zircon+tourmaline + rutile $)=63$, the lowest values found in the basin, and RZ (rutile+zircon) $=6$. The quantitative analysis further revealed the prevalence of sub-angular to rounded anhedric zircon grains (83\%), with euhedric and subhedric to subangular anhedric tourmaline grains (79\%) (Tab. II).

\section{GRAMAME/ITAMARACÁ FORMATIONS}

The Beberibe Formation is overlain by the carbonatic Gramame/Itamaracá Formations that show a few mappable occurrences only in the southeastern part of the study area, in the Abiaí depression located in the adjacency of the town of Alhandra (Fig. 3). Distinction between these two units, or between them and the overlying Maria Farinha Formation, was not attempted in the present work, because data derived from wells completely lack this information and also because the main focus was the siliciclastic 


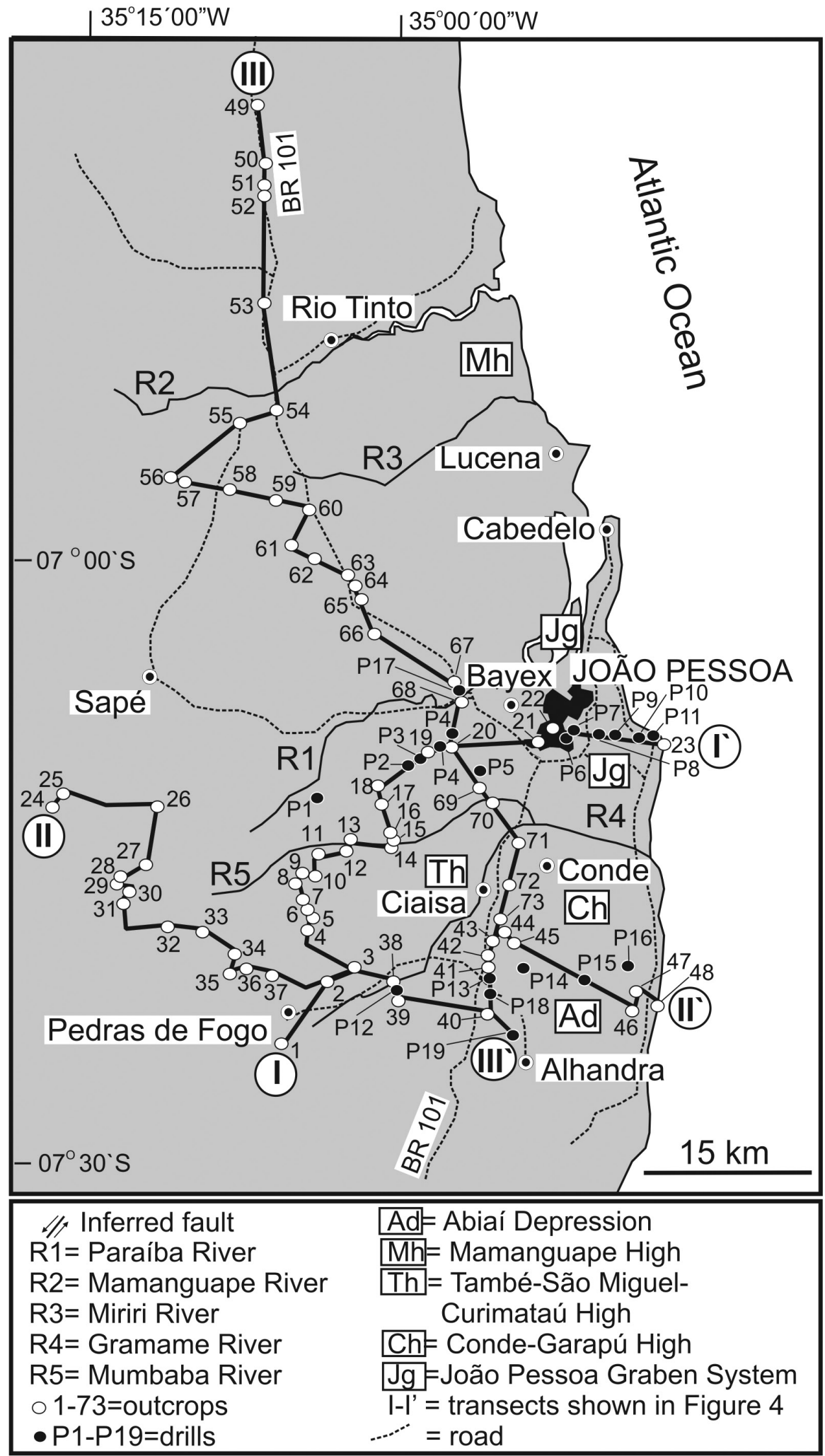

Figure 3: Location of the studied exposures, drills and transects, with the interpreted distribution of the stratigraphic units. 

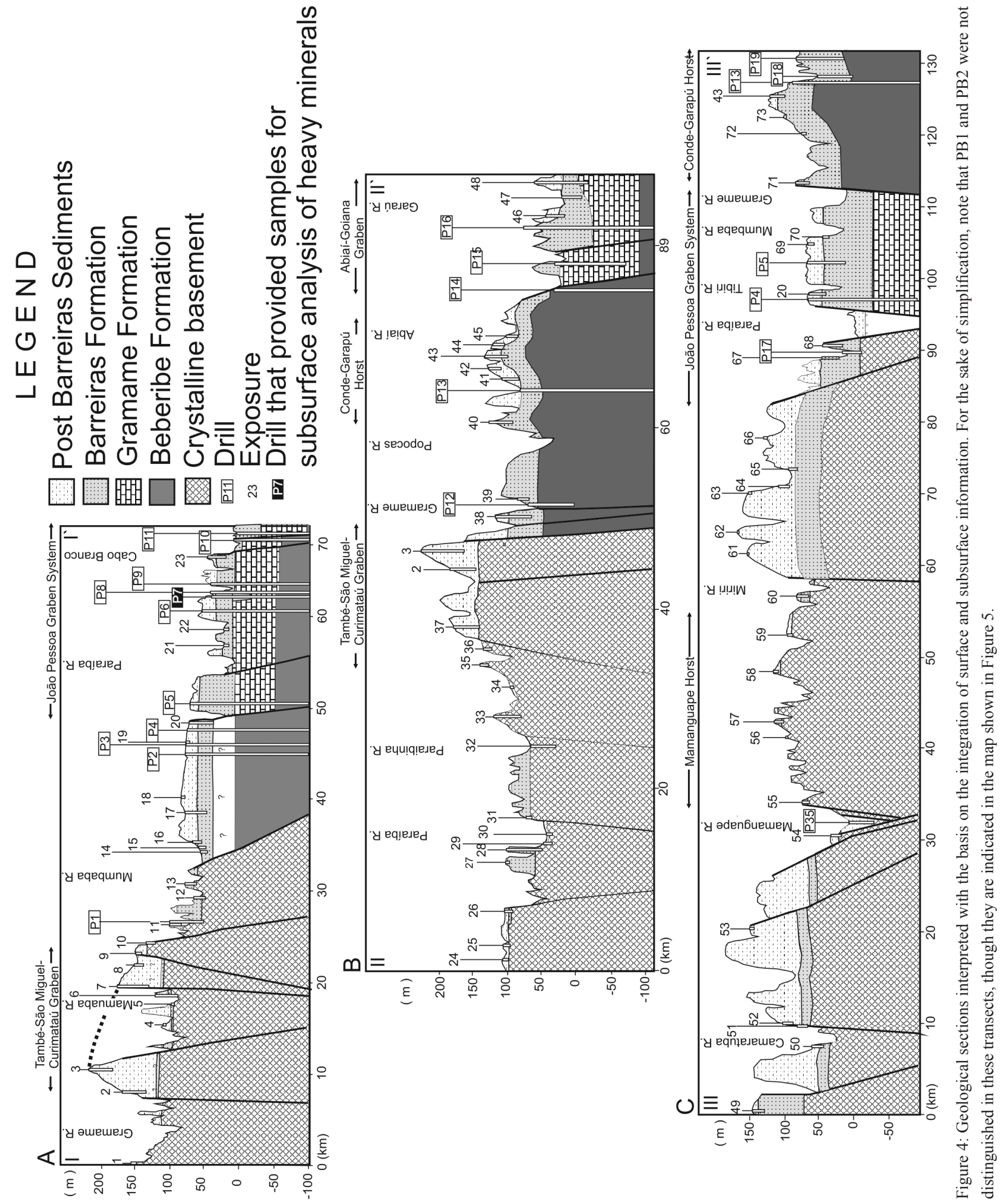


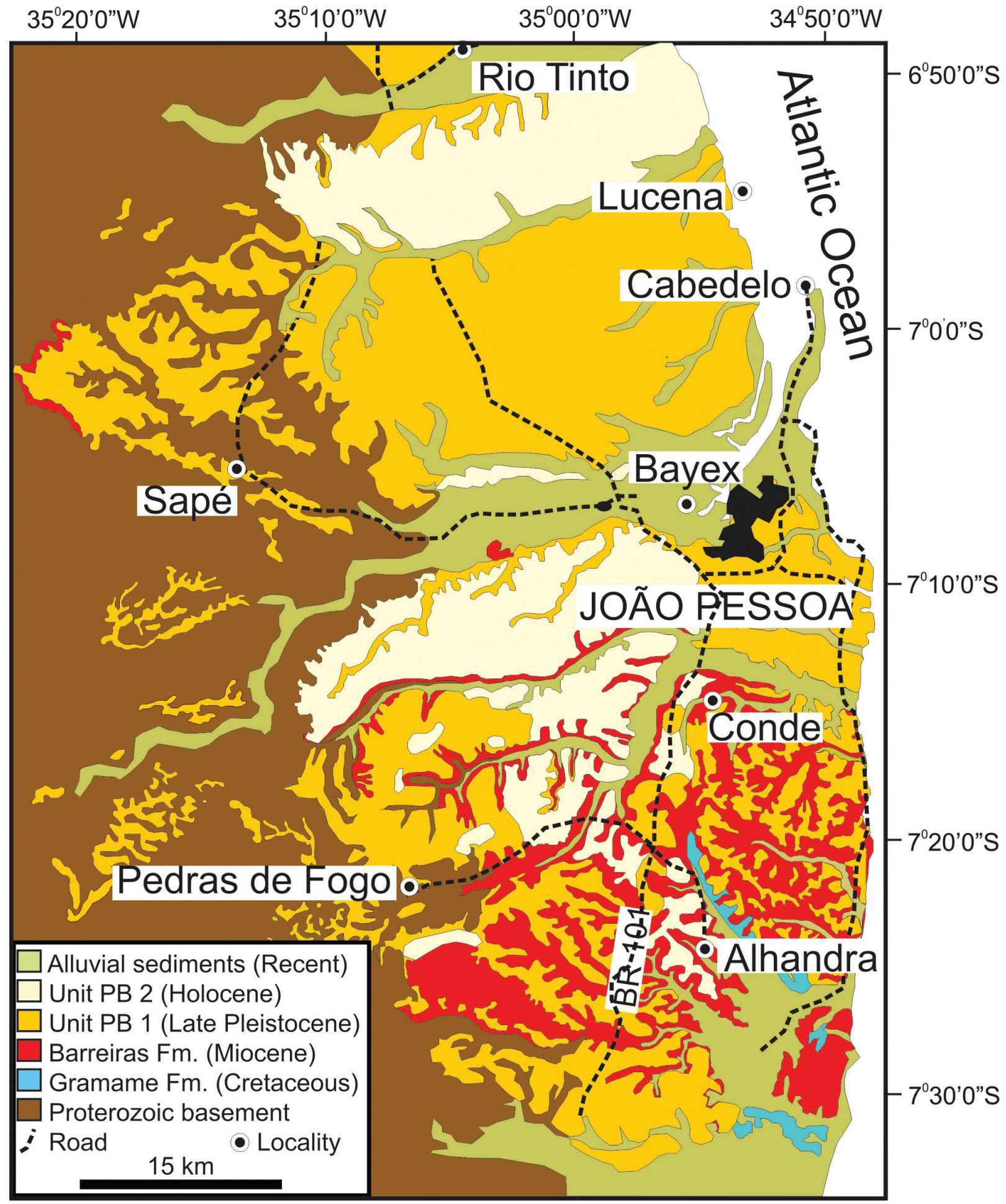

Figure 5: Geological map for the study area. 
TABLE I

Frequency of heavy minerals of the studied geological units.

\begin{tabular}{cccccccccccccc}
\hline $\begin{array}{c}\text { STRATIGR. } \\
\text { UNIT }\end{array}$ & $\begin{array}{c}\# \\
\text { SAMP. }\end{array}$ & $\begin{array}{c}\mathrm{Z} \\
\%\end{array}$ & $\begin{array}{c}\mathrm{Tu} \\
\%\end{array}$ & $\begin{array}{c}\mathrm{R} \\
\%\end{array}$ & $\begin{array}{c}\mathrm{Ky} \\
\%\end{array}$ & $\begin{array}{c}\mathrm{St} \\
\%\end{array}$ & $\begin{array}{c}\mathrm{Ad} \\
\%\end{array}$ & $\begin{array}{c}\text { Anf } \\
\%\end{array}$ & $\begin{array}{c}\mathrm{Tp} \\
\%\end{array}$ & $\begin{array}{c}\mathrm{Gr} \\
\%\end{array}$ & $\begin{array}{c}\mathrm{O} \\
\%\end{array}$ & $\mathrm{ZTR}$ & $\mathrm{RZ}$ \\
\hline PB2 & 13 & 68 & 16 & 5 & 7 & 2 & 1 & 0 & 0 & 0 & 0 & 90 & 8 \\
PB1 & 67 & 55 & 25 & 5 & 9 & 2 & 2 & 0 & 1 & 0 & 1 & 85 & 9 \\
Barreiras & 49 & 51 & 25 & 4 & 11 & 4 & 2 & 1 & 2 & 0 & 0 & 79 & 10 \\
Itamaracá & 2 & 45 & 26 & 4 & 17 & 5 & 0 & 1 & 0 & 0 & 2 & 75 & 7 \\
\hline Beberibe & 8 & 49 & 10 & 4 & 9 & 1 & 1 & 1 & 0 & 24 & 1 & 63 & 6 \\
\hline
\end{tabular}

TABLE II

Morphology of zircon and tourmaline grains from the studied geological units.

\begin{tabular}{ccccccccc}
\hline $\begin{array}{c}\text { STRATIGR. } \\
\text { UNIT }\end{array}$ & $\begin{array}{c}\# \\
\text { SAMP. }\end{array}$ & $\begin{array}{c}\mathrm{Za} \\
\%\end{array}$ & $\begin{array}{c}\mathrm{Zb} \\
\%\end{array}$ & $\begin{array}{c}\mathrm{Zc} \\
\%\end{array}$ & $\begin{array}{c}\# \\
\text { SAMP. }\end{array}$ & $\begin{array}{c}\mathrm{Ta} \\
\%\end{array}$ & $\begin{array}{c}\mathrm{Tb} \\
\%\end{array}$ & $\begin{array}{c}\mathrm{Tc} \\
\%\end{array}$ \\
\hline PB2 & 7 & 8 & 38 & 54 & 13 & 20 & 20 & 60 \\
PB1 & 37 & 9 & 43 & 48 & 64 & 26 & 33 & 41 \\
Barreiras & 42 & 10 & 45 & 45 & 49 & 28 & 41 & 31 \\
Itamaracá & 2 & 21 & 49 & 31 & 2 & 37 & 41 & 22 \\
\hline Beberibe & 8 & 17 & 55 & 28 & 8 & 42 & 37 & 21 \\
\hline
\end{tabular}

$\mathrm{Za} / \mathrm{Ta}=$ euhedric and subhedric zircon/tourmaline

$\mathrm{Zb} / \mathrm{Tb}=$ anhedric subangular zircon/tourmaline

$\mathrm{Zc} / \mathrm{Tc}=$ anhedric subrounded/rounded zircon/tourmaline

units, as previously mentioned. The analysis of the studied transects revealed that the GramameItamaracá Formations were deposited in areas with high subsidence near the coastline, where fault activity displaced the Beberibe Formation several tens of meters, creating space to accommodate new sediments. The analysis of two samples from the calciferous sandstone at the base of this succession, probably corresponding to the Itamaracá Formation, indicated the prevalence of zircon (45\%), tourmaline (26\%) and kyanite $(17 \%)$ in the heavy mineral assemblage, the latter displaying the highest values of all units (Tab. I). Staurolite, rutile, amphibole and other minerals occur subordinately, altogether summing $12 \%$. $R Z=7$ is close to the values recorded in the Beberibe Formation, but $\mathrm{ZTR}=75$ is slightly higher than this unit, approaching the values obtained for the overlying Barreiras Formation. Zircon and tourmaline grains display morphologies comparable to the Beberibe Formation, which was indicated by the prevalence of subangular anhedric to subrounded to rounded anhedric zircon $(80 \%)$ and anhedric to euhedric tourmaline (78\%) (Tab. II).

\section{BARREIRAS FORMATION}

The present mapping of sedimentary units in surface using outcrop and remote sensing information for a great part of the Paraíba Basin shows a widespread geographic distribution of the Barreiras 
Formation in the southern sector of the map, corresponding mostly to the Alhandra Sub-Basin, where this unit occurs in altitudes ranging from 12 to $159 \mathrm{~m}$. In surface, the Barreiras Formation is chiefly characterized by moderate to very steep reliefs (Tab. III), with convex to concave profile curvature (Tab. IV) and planar $\left(-0.054 \mathrm{a}+0.054^{\circ} / \mathrm{m}\right)$ or divergent $\left(>+0.180^{\circ} / \mathrm{m}\right)$, and secondarily by a slightly divergent $\left(+0.054\right.$ a $\left.+0.180^{\circ} / \mathrm{m}\right)$ plan curvature (Tab. V). The interpreted geological sections indicate that these strata are thicker where they overlie older sedimentary units to the east, being thinner westward over the crystalline basement. Significant thickness gradients are recorded in the Barreiras Formation within short distances. Noteworthy is also its almost complete absence in the Mamanguape High, an intensely dissected basement area between the Mamanguape and Miriri Rivers (transect III-III' in Fig. 4), and in highland areas of the crystalline basement between the Paraiba and Gramame Rivers (transect II-II' in Fig. 4; see also the area between the Gramame and Mumbaba Rivers in transect I-I', Fig. 4), referred to as També-São Miguel-Curimataú Horst in a previous publication (Brito Neves et al. 2009). It also appears, though only as a thin veneer, in the highlands between the Gramame and Mumbaba Rivers (transect I-II' in Fig. 4).

TABLE III

Declivity of the geological units exposed in the onshore area of the Paraíba Basin

\begin{tabular}{|c|c|c|c|c|c|c|}
\hline \multirow{2}{*}{ Stratigraphic Unit } & \multicolumn{7}{|c|}{ Classes* $^{*}$} \\
\cline { 2 - 7 } & 1 & 2 & 3 & 4 & 5 & 6 \\
\hline PB2 (56) & 14 & 64 & 14 & 7 & 0 & 0 \\
\hline PB1 (64) & 1 & 48 & 42 & 9 & 0 & 0 \\
\hline Barreiras Fm. (17) & 0 & 47 & 53 & 0 & 0 & 0 \\
\hline Gramame Fm. (4) & 0 & 100 & 0 & 0 & 0 & 0 \\
\hline $\begin{array}{c}\text { Crystalline } \\
\text { Basement (22) }\end{array}$ & 0 & 77 & 18 & 5 & 0 & 0 \\
\hline
\end{tabular}

(*) Class 1 (plan): 0 to $3 \%$; class 2 (gentle): 3 to $8 \%$; class 3 (moderate): 8 to $20 \%$; class 4 (steep): 20 to $45 \%$; class 5 (very steep): 45 to $75 \%$; class 6 (overhanging): above $75 \%$.

TABLE IV

Profile curvature of the geological units exposed in the onshore area of the Paraíba Basin.

\begin{tabular}{|c|c|c|c|c|c|}
\hline \multirow{2}{*}{ Stratigraphic Unit } & \multicolumn{5}{|c|}{ Classes* } \\
\cline { 2 - 6 } & 1 & 2 & 3 & 4 & 5 \\
\hline PB2 (56) & 11 & 25 & 13 & 7 & 45 \\
\hline PB1 (64) & 27 & 6 & 5 & 18 & 42 \\
\hline Barreiras Fm. (17) & 35 & 5.9 & 6 & 6 & 47 \\
\hline Gramame Fm. (4) & 50 & 50 & 0 & 0 & 0 \\
\hline $\begin{array}{c}\text { Crystalline } \\
\text { Basement (22) }\end{array}$ & 32 & 23 & 0 & 9 & 36 \\
\hline
\end{tabular}

(*) Class 1 (concave): $<-0.005 \mathrm{o} / \mathrm{m}$; class 2 (slightly concave): -0.005 to $-0.00125 \mathrm{o} / \mathrm{m}$; class 3 (straight): -0.00125 to $+0.00125 \mathrm{o} / \mathrm{m}$; class 4 (slightly convex): +0.00125 to $+0.005 \mathrm{o} / \mathrm{m}$; class 5 (convex): $>+0.005 \mathrm{o} / \mathrm{m}$. 
TABLE V

Plan curvature of the geological units exposed in the onshore area of the Paraíba Basin.

\begin{tabular}{|c|c|c|c|c|c|}
\hline \multirow{2}{*}{ Stratigraphic Unit } & \multicolumn{5}{|c|}{ Classes* $^{*}$} \\
\cline { 2 - 6 } & 1 & 2 & 3 & 4 & 5 \\
\hline PB2 (56) & 7 & 14 & 27 & 29 & 23 \\
\hline PB1 (64) & 12 & 11 & 11 & 32 & 28 \\
\hline Barreiras Fm. (17) & 12 & 12 & 29 & 18 & 29 \\
\hline Gramame Fm. (4) & 25 & 50 & 0 & 0 & 25 \\
\hline $\begin{array}{c}\text { Crystalline } \\
\text { Basement (22) }\end{array}$ & 41 & 6 & 18 & 6 & 29 \\
\hline
\end{tabular}

(*) Class 1 (convergent): $<-0.180^{\circ} / \mathrm{m}$; class 2 (slightly convergent): -0.180 to $-0.054^{\circ} / \mathrm{m}$; class 3 (planar): -0.054 to $+0.054^{\circ} / \mathrm{m}$; class 4 (slightly divergent): $+0,054$ to $+0,180^{\circ} / \mathrm{m}$; class 5 (divergent): $>+0.180^{\circ} / \mathrm{m}$.

Exposures of the Barreiras Formation consist, in general, of moderately sorted, very fine- to coarse-grained sandstones with colors varying from white, pink, yellow, purple to red. Sandstones are interfingered with either massive or parallel laminated shales and, secondarily, with conglomerates composed mostly of quartz pebbles supported by a medium- to coarse-grained sandy matrix. The deposits are commonly organized into fining upward successions, and might contain abundant ichnofossils such as Ophiomorpha, Thallassinoides, Skolithos, Planolites and Diplocraterion. Lithologies are often massive, which precludes a detailed facies analysis aiming to paleoenvironmental reconstructions. Less commonly, cross-stratified sandstones are present, when reactivation surfaces and mud drapes along foreset packages are frequent.

A striking feature of the Barreiras Formation is its high degree of ferruginization associated, directly or indirectly, with the concretionary horizon of the lateritic profile developed in its top and that was responsible for great part of the massive deposits that typify this unit. Noteworthy is that tectonic deformation disrupted this paleosol and the underlying strata, as recorded by faults, joints and, secondarily folds, the latter being particularly abundant in exposures located in the Conde-Garapu
Horst (see figures 3 and 4 of Rossetti et al. 2011). The process of paleosol formation was so intense that it locally altered the entire profiles to produce highly oxidized strata. Pedogenesis developed directly on exposed rocks of the underlying crystalline basement where the Barreiras Formation was absent, forming a ferruginous concretionary horizon in its top. Ferruginization took place also within the Barreiras Formation, which is probably related to descending iron-rich solutions during burial, a process controlled by lithological contrasts. (U+Th)/He dating of 19 samples of concretionary lateritic paleosol derived from the top of both the crystalline basement and the Barreiras Formation revealed ages ranging from 0.86 to $17.86 \mathrm{Ma}, 97 \%$ of which concentrated in the time-interval between 1 and $7 \mathrm{Ma}$, but with a peak concentration between 1 and 2 Ma (Fig. 6).

The analysis of 42 samples collected in surface throughout the study area, and seven samples collected in subsurface in the drill P7 (see Fig. 3 for location), revealed that the Barreiras Formation is composed mostly of zircon (51\%), tourmaline (25\%), kyanite (11\%) and, secondarily (13\%), rutile, staurolite, andaluzite, topaz and amphibole (Tab. I). The ZTR and RZ values correspond to 79 and 10, respectively. There is a significant increase in subangular to rounded anhedric zircons 


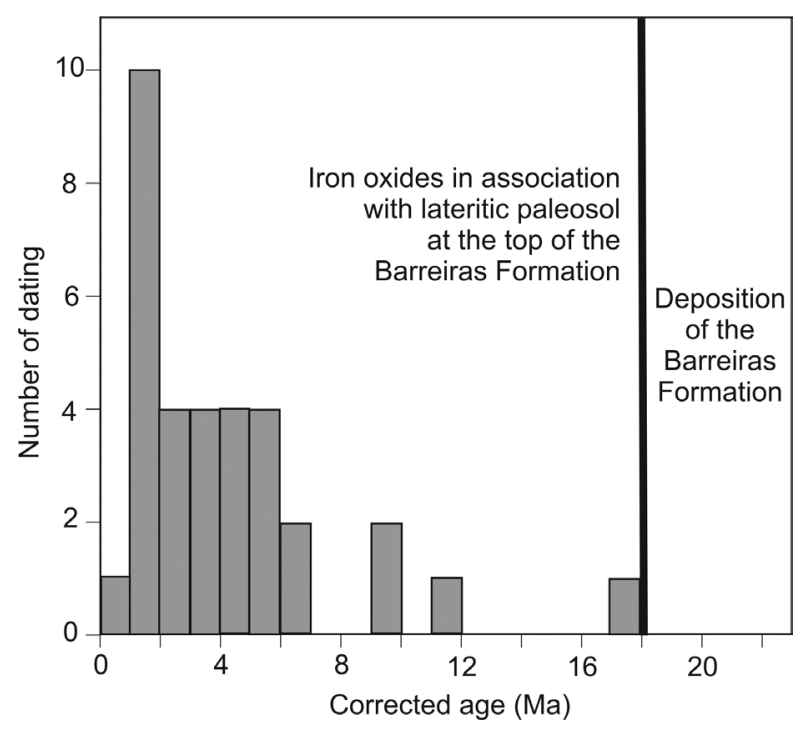

Figure 6: Distribution of $(\mathrm{U}+\mathrm{Th}) / \mathrm{He}$ ages of weathered goethite from the lateritic paleosol at the top of the Barreiras Formation.

(90\%) relative to the underlying units, which is accompanied also by an increase in the volume of euhedric to subhedric and subrounded anhedric tourmaline grains $(72 \%)$ (Tab. II).

A few thin sections were analyzed aiming to obtain additional criteria for distinguishing the Barreiras Formation from the Post-Barreiras Sediments in the study area. The results revealed that the Barreiras Formation consists mostly of quartz and, secondarily, of feldspar grains displaying mechanical compaction, which is indicated by the frequent presence of deformed ductile grains of mica and clay, the latter forming a pseudomatrix. The chemical compaction during burial is also indicated by grain-to-grain, straight and concave-convex contacts. In addition, booklets of authigenic kaolinite are frequently found filling interstitial porosities.

\section{POST-BARREIRAS SEDIMENTS}

These deposits are better represented in the middle and northern parts of the mapped area, where they cover continuous plateaus that are interrupted only by the alluvial sedimentation of modern river valleys. Additionally, they also occur in the southern part of the basin as discontinuous deposits overlying the Barreiras Formation. The Post-Barreiras Sediments are located at altitudes ranging from 1 to $200 \mathrm{~m}$, where they form reliefs that are smoother than those of the Barreiras Formation, in general varying from plan to moderate, with a higher concentration of gentle terrains (Tab. III). These are characterized mostly by convex $\left(>+0.005^{\circ} / \mathrm{m}\right)$ and slightly divergent $(+0.054$ to $\left.-0.180^{\circ} / \mathrm{m}\right)$ to divergent $\left(>0.180^{\circ} / \mathrm{m}\right)$ profile and plan curvatures (Tabs. IV and V).

The Post-Barreiras Sediments constitute two stratigraphic intervals, designated herein as PB1 and PB2 (Fig. 5), which occur in terrains that are morphologically distinctive. Hence, terrains corresponding to unit PB1 stand at the highest topography in the study area, in general between $100 \mathrm{~m}$ and $150 \mathrm{~m}$, with local elevations up to $200 \mathrm{~m}$, while prevailing elevations in unit PB2 are lower than $100 \mathrm{~m}$. In addition, the PB1 unit shows higher slopes (mode values between $2 \%$ and $10 \%$ ), and stronger curvatures, while PB2 uniformly characterizes flat terrains located below $2 \%$ slopes and with straight profiles (curvature within the $+/-0.005 \mathrm{o} / \mathrm{m}$ interval) (see Tabs. III to V). Other morphometric distinctions are consequences of these primary differences, as are the majority of straight-convergent and straight-divergent conditions among PB2 mapped landforms. Contrastingly, all field observations on concave-divergent terrains correspond to PB1 deposits; $72 \%$ of the observations on straightplanar terrain were related to occurrences of unit PB2. Another consistent morphometric implication of the flat character of PB2 unit is its very low coherence values, which contrast with the well-defined slopes of PB1 terrain, where steep and curved surfaces allow a higher organization of aspect distribution, with pattern variations, defining the structure of surface hydrology in slopes, drainage and divides. Under 
this condition, coherence is generally high, with the low coherence values indicating local singularities, thalwegs and ridges.

Lithologically, unit PB1 is typically composed of golden yellow endured sandstones and breccias either with massive bedding or a large variety of ductile and brittle deformation structures (i.e., massive sandstones with isolated sand fragments and breccias, undulatory strata, sand dykes and diapirs, sinks and bowls, pebbly pockets, plunged sediment mixtures, fitted sand masses, cone-shaped cracks, fault grading and sedimentary enclaves). These features, fully described and illustrated in Rossetti et al. (2011), have been related by these authors to seismic shocks of high surface-wave magnitude (i.e., $\mathrm{Ms}>5$ or 6 ) that took place contemporaneous to or shortly after sediment deposition. Unit PB1 also includes a large volume of non-indured and undeformed deposits. These include sharply bounded, fining upward massive or stratified conglomerates and sandstones interbedded with mudstones, as well as massive, poorly sorted sandstones commonly with dispersed granules and clasts of laterite concretions. These strata are related to fluvial environments and debris flows, though they might include nearshore marine-influenced strata in areas located nearby the modern coastline, as suggested by the presence of burrows such as Skolithos, Thalassinoides, Planolites, Diplocraterion, and Teichichnus (Rossetti et al. 2011).

The petrographic analysis of the endured deposits from unit PB1 revealed a framework composed mostly of quartz grains, which are extensively fractured, a characteristic not associated with the underlying Barreiras Formation. Additional differences between these units include the relatively more open framework in PB1, characterized by grains that are floating within a muddy matrix, as well as the absence of authigenic minerals. As opposed to the Barreiras Formation, unit PB1 displays a matrix produced by the mechanical introduction of mud within sand, rather than a matrix resulting from the compaction of muddy grains. Structures related to fluidization and bioturbation were frequently observed in the thin sections of unit PB1, and these processes might have responded to re-sedimentation and mixing of sands and muds.

Unit PB2 overlies the previously described deposits, as well as the Barreiras Formation, from which it separates through a discontinuity surface characterized by an irregular erosional relief of a few meters at the outcrop scale. The bulk of unit PB2 is much less complex than deposits from unit PB1, consisting exclusively of friable, white to gray or brown, well sorted, rounded to subrounded, quartz sands that are either massive or display dissipation dune structures.

In addition to the above described characteristics, OSL dating of 39 samples further demonstrates that units PB1 and PB2 constitute deposits that are different from the Barreiras Formation. Hence, PB1 and PB2 are related to time intervals between $74.8 \pm 9.3$ and $30.8 \pm 6.9 \mathrm{ka}$, and $8.8 \pm 0.9$ and $1.8 \pm 0.2 \mathrm{ka}$, respectively (Tab. VI). Mineralogically, there is not much difference between these units, except for a higher proportion of zircon $(69 \%)$, a lower volume of tourmaline $(16 \%)$ and a slight increase in ZTR (90) in unit PB2, while in PB1 these values are $55 \%, 25 \%$ and 85 , respectively ( $\mathrm{Tab}$. I). Noteworthy is that the PB1 unit is compositionally more similar to the Barreiras Formation than to unit PB2. In addition, zircon morphology in PB1 and PB2 is similar to the one in the Barreiras Formation. The proportion of subangular to rounded anhedric tourmaline increases progressively in units PB1 (74\%) and PB2 (80\%), and the proportion of kyanite decreases with respect to the Barreiras Formation.

\section{DISCUSSION}

The data provided in this work represent one step forward to the characterization of siliciclastic sedimentary units of the onshore Paraíba Basin, adding new elements to resolve its stratigraphic framework. 
TABLE VI

Optically Stimulated Luminescence (OSL) dating of the Post-Barreiras Sediments.

\begin{tabular}{|c|c|c|c|c|c|c|c|}
\hline Unit & Sample & $\mathbf{U}(\mathbf{p p m})$ & Th(ppm) & $\mathbf{K}(\%)$ & $\begin{array}{c}\text { Accumulated } \\
\text { dose (Gy) }\end{array}$ & $\begin{array}{l}\text { Annual dose } \\
\text { rate }(\mu \mathrm{Gy} / \mathbf{y r})\end{array}$ & Age (ka) \\
\hline \multirow{33}{*}{ PB1 } & $26-7$ & 2.643 & 11.748 & 0.298 & 31.4 & $2068 \pm 84$ & $15.2 \pm 1.4$ \\
\hline & $26-8$ & 2.237 & 9.200 & 0.151 & 40.2 & $1622 \pm 50$ & $24.8 \pm 2.0$ \\
\hline & $20-8$ & 1.510 & 7.228 & 0.151 & 71.0 & $1416 \pm 80$ & $50.2 \pm 5.4$ \\
\hline & $20-9$ & 2.094 & 9.058 & 0.505 & 44.5 & $2090 \pm 183$ & $21.3 \pm 2.9$ \\
\hline & $20-10$ & 3.207 & 15.313 & b.d.l & 48.0 & $2590 \pm 217$ & $18.5 \pm 2.5$ \\
\hline & $68-8$ & 2.455 & 10.917 & 0.462 & 60.0 & $2126 \pm 102$ & $28 . \pm 4.0$ \\
\hline & $68-13$ & 1.423 & 6.142 & 0.550 & 49.0 & $1591 \pm 142$ & $30.8 \pm 6.9$ \\
\hline & $68-14$ & 1.098 & 3.878 & 0.272 & 51.0 & $1053 \pm 74$ & $48.4 \pm 5.1$ \\
\hline & 66-3 & 0.542 & 1.168 & b.d.1 & 19.2 & $511 \pm 6$ & $37.6 \pm 2.3$ \\
\hline & $66-4$ & 1.080 & 1.278 & b.d.1 & 20.0 & $439 \pm 35$ & $45.6 \pm 5.9$ \\
\hline & $62-1$ & 0.611 & 1.242 & 0.426 & 31.5 & $1003 \pm 219$ & $31.4 \pm 8.4$ \\
\hline & $61-1$ & 0.720 & 0.753 & b.d.1 & 23.4 & $492 \pm 20$ & $47.5 \pm 4.3$ \\
\hline & $61-2$ & 0.472 & 0.724 & 0.093 & 29.4 & $521 \pm 76$ & $56.4 \pm 11.1$ \\
\hline & $53-1$ & 2.720 & 12.862 & 0.533 & 184.0 & $2413 \pm 118$ & $76.0 \pm 9.1$ \\
\hline & $53-2$ & 2.493 & 12.143 & 0.589 & 85.0 & $2358 \pm 123$ & $36.0 \pm 2.8$ \\
\hline & $53-3$ & 0.884 & 2.081 & 0.524 & 28.0 & $1122 \pm 116$ & $25.0 \pm 2.7$ \\
\hline & $50-1$ & 2.046 & 7.508 & 0.549 & 125.0 & $1853 \pm 165$ & $67.5 \pm 9.2$ \\
\hline & $50-2$ & 1.226 & 3.691 & 0.188 & 18.0 & $968 \pm 57$ & $19.0 \pm 1,9$ \\
\hline & $50-10$ & 1.937 & 6.437 & 0.282 & 70.0 & $1471 \pm 134$ & $48.0 \pm 5.1$ \\
\hline & 50-11 & 2.444 & 12.738 & 0.396 & 78.0 & $2192 \pm 125$ & $35.6 \pm 3.4$ \\
\hline & $102-4$ & 3.051 & 14.502 & 0.538 & 39.6 & $2613 \pm 185$ & $15.2 \pm 1,8$ \\
\hline & $102-5$ & 0.785 & 1.314 & b.d.1 & 26.9 & $551 \pm 50$ & $48.8 \pm 6.9$ \\
\hline & 103-3 & 2.021 & 8.655 & 0.284 & 51.9 & $1662 \pm 151$ & $31.2 \pm 4.4$ \\
\hline & $106-1$ & 0.683 & 1.353 & b.d.l & 11.2 & $521 \pm 42$ & $21.5 \pm 2.8$ \\
\hline & $72-2$ & 2.124 & 9.950 & 0.211 & 39.2 & $1760 \pm 159$ & $22.3 \pm 3.1$ \\
\hline & $72-3$ & 1.628 & 7.842 & 0.467 & 27.0 & $1686 \pm 112$ & $16.0 \pm 1.9$ \\
\hline & $48-2$ & 3.935 & 18.265 & 0.899 & 53.0 & $3506 \pm 240$ & $15.1 \pm 1.8$ \\
\hline & $48-5$ & 3.637 & 19.442 & 0.460 & 131.3 & $3068 \pm 159$ & $42.8 \pm 4.4$ \\
\hline & $48-7$ & 4.477 & 23.062 & 0.607 & 213.5 & $3707 \pm 189$ & $57.6 \pm 5.8$ \\
\hline & 116-1 & 0.715 & 1.410 & b.d.1 & 11.2 & $521 \pm 42$ & $21.5 \pm 2.8$ \\
\hline & $119-4$ & 4.879 & 26.098 & 0.738 & 116.6 & $4172 \pm 340$ & $27.9 \pm 3.7$ \\
\hline & $119-5$ & 4.031 & 18.952 & 1.120 & 285.0 & $3809 \pm 283$ & $74.8 \pm 9.3$ \\
\hline & 129.3 & 2.799 & 15.553 & 0.638 & 489.0 & $2743 \pm 276$ & $178.3 \pm 26.8$ \\
\hline \multirow{6}{*}{ PB2 } & $26-5$ & 1.298 & 5.446 & 0.141 & 9.6 & $1088 \pm 53$ & $8.8 \pm 0.9$ \\
\hline & $26-6$ & 1.674 & 5.903 & 0.578 & 18.9 & $1667 \pm 165$ & $11.3 \pm 1.7$ \\
\hline & $68-10$ & 1.547 & 5.129 & 0.245 & 2.5 & $1235 \pm 58$ & $2.0 \pm 0.2$ \\
\hline & 68-11 & 1.419 & 4.496 & 0.219 & 2.0 & $1128 \pm 54$ & $1.8 \pm 0.2$ \\
\hline & $50-3$ & 0.754 & 2.194 & 0.215 & 4.6 & $780 \pm 42$ & $6.0 \pm 0.6$ \\
\hline & $102-3$ & 4.366 & 24.443 & b.d.1 & 15.1 & $3299 \pm 168$ & $4.6 \pm 0.5$ \\
\hline
\end{tabular}


ESTABLISHING STRATIGRAPHIC CRITERIA

Two points of relevance need to be addressed before approaching the stratigraphic context of the Paraíba Basin, which include: (1) definition of localities with occurrences of the Beberibe Formation and its distinction from overlying siliciclastic units; and (2) distinction between the Post-Barreiras Sediments and the underlying Barreiras Formation. The following discussion approaches these issues.

Due to their carbonatic nature, the ItamaracáGramame Formations can be regarded as an excelent stratigraphic marker to separate the underlying Beberibe Formation from overlying siliciclastic units deposited during the Cenozoic. However, this distinction is not so straightforward where these carbonate units are absent. A detailed analysis of heavy mineral assemblages combining data from a large volume of exposures of siliciclastic units with a continuous core in João Pessoa (i.e., core P7 in figure 3) contributed significantly to resolve this issue. The fact that in this core the ItamaracáGramame carbonatic succession separates the Beberibe Formation from the Cenozoic strata was of great help to establish the stratigraphy in this area. The high volume of garnet (a mineral absent in the overlying strata) and the low volume of tourmaline in the Beberibe Formation are remarkable, allowing its differentiation from any other siliciclastic deposits that occur either in surface or in subsurface. In addition, the Beberibe Formation displays the lowest ZTR, added to the highest proportion of euhedric to subhedric tourmaline. The absence of comparable characteristics in any other analyzed siliciclastic units assures that the Beberibe Formation is not recorded at surface along the study area. Thus, the endured sandstones, previously mapped as the Beberibe Formation along a large area of the basin (see figure 1 of Brito Neves et al. 2009), are actually included in the Post Barreiras Sediments. In addition to the presence of exposures displaying these deposits overlying the Barreiras Formation, the fact that only Late Pleistocene OSL ages were recorded in these strata confirms their attribution to unit PB1.

The Barreiras Formation in northern Brazil is defined as a highly oxidized and locally ferrified, lower to middle Miocene unit bounded both in its base and top by unconformities with lateritic paleosols (Rossetti et al. 1989, Rossetti 2000, 2004). This unit is overlain by Late Pleistocene to Holocene strata included in the informal term Post-Barreiras Sediments (e.g., Tatumi et al. 2008). There is no attempt to stratigraphically formalize these deposits in the present article, a task that must be completed in a near future. Although the age of the Barreiras Formation in the Paraíba Basin could not be determined, supergene (U+Th)/ He goethite ages up to $17.86 \mathrm{Ma}$, with $97 \%$ concentrated between 1 and 7 Ma derived from the paleosol associated with the upper unconformity, is consistent with its proposed deposition in the Miocene. It is noteworthy that ages up to $22 \mathrm{Ma}$ were previously indicated for goethite crystals at the top of the Barreiras Formation (Lima 2008). In addition to the absence of garnet and higher volume of tourmaline, the lower proportion of euhedric zircon, as well as the significantly higher proportion of euhedric to subhedric and subangular anhedric tourmaline, might be useful to differentiate this unit from the Beberibe Formation in subsurface. In general, except for the progressive upward increase in the proportion of subangular to rounded anhedric tourmaline and decrease in kyanite, heavy minerals did not help much to distinguish the Barreiras Formation from the Post-Barreiras Sediments, particularly in the instance of unit PB1. This only suggests that, as expected, the Post-Barreiras Sediments were reworked from the underlying Barreiras Formation.

Despite the above mentioned compositional similarity, the data presented herein lead us to state that, as in northern Brazil, the Post-Barreiras Sediments in the Paraíba Basin constitute a unit 
chronologically distinct from underlying strata. Key features associated only with the PostBarreiras Sediments include: (1) the unconformable nature of the lower boundary, wherever exposed, which is usually marked by extensive lateritic paleosol; (2) the lack of ferrified deposits, which is characteristical only of the Barreiras Formation; (3) the record of only Late Pleistocene and Holocene OSL ages; (4) the presence of clasts of laterite that have been reworked from the underlying paleosol; (5) the occurrence of highly, golden yellow endured deposits typically displaying a variety of soft sediment deformation structures; (6) the lack of any evidence for diagenetic modification, as opposed to the Barreiras Formation, where evidence for burial is present; and (7) the occurrence of highly fractured quartz grains in the endured sandstones. Amongst these, characteristics (1), (2), (4) and (5) can be applied to distinguish the Post-Barreiras Sediments in the field.

In addition to the features highlighted above, the convex, slightly divergent to divergent plane to smoothly undulating terrains of the Post-Barreiras Sediments differs from the convex to concave and planar to divergent, hilly to undulating reliefs typical of the Barreiras Formation. These dissimilarities reflect the differential time of exposure of these units to surface processes, probably added to their tectonic histories.

The two stratigraphic units of the PostBarreiras Sediments were distinguished mainly with the basis on the following characteristics: (1) the presence of the discontinuity surface with an erosional relief between units; (2) the friable sand composition of unit PB2 that differs from endured sandstones or soft, but not loose, sandstones and mudstones of unit PB1; (3) the OSL Holocene age of unit PB2 that contrasts with the Late Pleistocene age of unit PB1; and (4) the occurrence of PB2 in dominantly straight-planar flat terrains with lower topographies relatively to the concave-divergent terrains characteristic of unit PB1.
TECTONO-SEDIMENTARY HISTORY

The geological sections described herein show the confinement of Cretaceous units to the east onshore part of the basin. The great differences in thicknesses within short distances, the abrupt lateral contact with the crystalline basement, and the occurrence of thick sedimentary packages restricted to places where the basement could not be reached by cores several hundreds of meters deep, altogether support that the preservation of Cretaceous deposits was only favored in areas undergone tectonic displacement. Although further investigation is still required to map the tectonic structures in detail, the geologic context leads us to interpret that faults due to rifting during the early stages of the basin development were the main control of sediment deposition. In fact, the organization of the sedimentary pile is better explained considering the presence of several faults, with the main suggested ones being depicted in the transects of Figure 4. The morphological analysis confirms the prompt matching of these faults with significant lineaments that contain many river valleys in the study area. Some of these have been previously linked to fault zones of the Paraíba, Mamanguape and Miriri Rivers (see references to these faults in Barbosa et al. 2003, Barbosa and Lima Filho 2006, Brito Neves et al. 2009). Other fault zones intercepted by the analyzed transects define the main courses of important drainages, for instance the Gramame, Mumbaba, Mamuaba and Paraiba Rivers (Fig. 3).

Hence, subsidence promoted by faulting allowed a thick sedimentary succession, represented by the Beberibe Formation, to accumulate within depressions formed in the eastern part of the study area, mostly corresponding to the João Pessoa and Goiana graben systems (Barbosa and Lima Filho 2006). The latter is preferentially designated herein as the Abaiaí-Goiana graben system to include the morphological depression well expressed in the lowermost Abiaí River. Additionally, the Beberibe 
Formation is well represented in the Conde-Garapú Horst (Barbosa and Lima Filho 2006), also referred to as the Conde-Caaporã monoclinal (Brito Neves et al. 2009). The Ciaisa Horst, described by these authors as a structure located a few kilometers southwest of Conde, might represent the western extent of this high.

Fault activity continued after the deposition of the Beberibe Formation in the Coniacian to Campanian, which resulted in the subsequent displacement of this unit for more than a hundred meters. This process produced a new accommodation space, where a thick carbonatic succession, represented mostly by the Itamaracá and Gramame Formations, was deposited up to the end of the Maastrichtian. The João Pessoa and Abiaí-Goiana graben systems continued to show high subsidence up to this time (Barbosa and Lima Filho 2006). Noteworthy is the absence of carbonatic successions in the area corresponding to the Conde-Garapú Horst, where the underlying Cretaceous unit is otherwise thick. Based on this information, the most likely way to interpret this area is as a higher landform bordering the graben systems, which was protected from marine transgression. Alternatively, one could suggest that this area was uplifted when the carbonatic rocks were completely eroded from the landscape. As discussed below, there is evidence of compressive structures affecting the Barreiras Formation in this sector. However, even considering uplift due to this compression, a significant erosion would be required for a thick succession of highly cemented rocks to be vanished completely from the paleolandscape. Therefore, the first explanation, i.e., non-deposition of this carbonatic succession on the Conde-Garapú Horst, seems to be the most likely one.

The distribution of both the Barreiras Formation and the Post-Barreiras Sediments throughout the study area leads us to propose that these deposits were also affected by tectonic deformation. The greatest thickness of these units overlying older sedimentary units accumulated in tectonic depressions and, in particular, the significant thickness gradients within short distances following the same pattern as the deposits below, are consistent with the tectonic deformation. The sedimentary features, mostly the cross-stratified sandstones with abundant reactivation surfaces and mud drapes, added to the ichnofossil assemblage related to coastal areas (Pemberton et al. 1992, Pemberton and Wightman 1992, MacEachern and Pemberton 1994), suggest that these deposits were formed in transitional marine environments. Similar paleoenvironmental interpretation was proposed for the Barreiras Formation exposed in northern Brazil (e.g., Rossetti et al. 1989, Rossetti 2000, 2004, 2006, Netto and Rossetti 2003) and, more recently, northeastern Brazil (Rossetti and Góes 2009, Rossetti and Dominguez in press). Thus, a marine transgression would have been responsible for filling with sediments the paleomorphology derived from fault displacement during the early/ middle Miocene. At the end of this period, sediment deposition was precluded, and subaerial exposure with erosion and pedogenesis under highly oxidizing conditions took place. This is recorded by both the pervasive sediment ferruginization and the unconformity with lateritic paleosol at the top of the Barreiras Formation. (U+Th)/He ages of goethite derived from this paleosol support its development during the late Miocene to Pleistocene.

The numerous faults, fractures, and even folds, that disrupt both the Barreiras Formation and the paleosol in its top, suggest relatively recent brittle and ductile tectonic deformations affecting extensive areas of the onshore Paraíba Basin (e.g., Nogueira et al. 2006, 2010). This event would have defined the modern relief, as well as the development of river valleys (Furrier et al. 2006, Bezerra et al. 2008). It was probably also responsible for the origin of the Post-Barreiras Sediments, at least of unit PB1. The several soft sediment deformation structures 
related to seismic shocks contemporaneous to or shortly after sediment deposition (Rossetti et al. 2011) support this proposition. A renewed phase of sediment deposition and seismicity in the Paraíba Basin during the Late Pleistocene can be suggested with the basis on the OSL ages provided for this unit. The end of sediment deposition in the study area took place in the Holocene, being documented by unit PB1, which included mostly sands reworked by fluvial and eolian processes along extensive elongated plateaus at the margins of the Mamanguape and Paraíba Rivers.

\section{CONCLUSIONS}

The approach consisting of surface and subsurface geological information, integrated with remote sensing and laboratory analysis presented herein, provided new geomorphological, sedimentological and stratigraphic parameters that, altogether, are invaluable to the characterization of siliciclastic units in onshore areas of the Paraíba Basin. Based on this study, we concluded that there are no deposits matching with descriptions of the Beberibe Formation exposed at the surface. This unit, which displays an assemblage of heavy minerals distinctive from all other sedimentary units of the basin, is constrained to the subsurface, where it underlies either limestones of the ItamaracáGramame-Maria Farinha succession or sandstones and mudstones of the Barreiras Formation and Post-Barreiras Sediments. The two latter units form the main sedimentary cover of the study area. The Barreiras Formation does not record only fluvial deposition as more often proposed, but also includes tidal influenced strata. In addition, deposition of this unit did not occur during the late Miocene or Pleistocene, but mostly before the latest Miocene, as recorded in other areas of the northern and northeastern Brazil. Like those regions, the Barreiras Formation in the Paraíba Basin is overlain by a significant volume of strata formed during the Late Pleistocene and Holocene, represented by units $\mathrm{PB} 1$ and $\mathrm{PB} 2$, referred herein also as the Post-Barreiras Sediments.

Tectonic deformation was a key factor to control the distribution of sedimentary units in the onshore Paraíba Basin, constraining the occurrence of all Cretaceous deposits to the east, i.e., along subsiding areas formed by fault displacements. Fault reactivation also interfered in the deposition of the Barreiras Formation. Hence, thicker strata were more often formed over tectonic depressions with Cretaceous deposits than over the crystalline basement. Following sediment deposition, the Barreiras Formation was further affected by both faulting and folding. Seismicity in this basin was in effect even in the Late Pleistocene, being responsible for widespread soft sediment deformation contemporaneous to the deposition of unit PB1.

\section{ACKNOWLEDGMENTS}

This work was supported by Fundação de Amparo à Pesquisa do Estado de São Paulo (FAPESP-Project \# 06/04687-7). HIDROTEC and, in particular, the geologist Ricardo Brandão, are acknowledged for providing the subsurface samples that completed the heavy mineral analysis. Except for the last author, all authors hold research grants from Conselho Nacional de Desenvolvimento Científico e Tecnológico (CNPq). We appreciate the several comments and corrections made by an anonymous reviewer, who contributed to improve the early version of the manuscript.

\section{RESUMO}

Várias publicações têm contribuído para melhorar a estratigrafia da Bacia Paraíba no nordeste do Brasil. Entretanto, a caracterização e distribuição das unidades sedimentares em áreas continentais desta bacia são ainda incompletas, apesar de sua importância para reconstruir a evolução tectono-sedimentar da margem passiva sulamericana. Este trabalho fornece novas informações 
para diferenciar entre estratos litologicamente similares que, por outro lado, não são relacionados no tempo. Esta abordagem incluiu descrições morfológica, sedimentológica e estratigráfica baseadas em dados de superfície e sub-superfície, integrada com sensoriamento remoto, datação por luminescência opticamente estimulada, datação de goetita intempérica por U+Th/ He e análise de minerais pesados. Baseado neste estudo, foi possível mostrar que unidades cretáceas são restritas à parte leste da porção continental da Bacia Paraíba. Exceto por poucos afloramentos de rochas carbonáticas próximo da linha de costa atual, depósitos desta idade não são expostos à superfície na área de estudo. Ao invés disto, a cobertura sedimentar ao longo da bacia é constituída por depósitos mineralogicamente e cronologicamente distintos, inseridos na Formação Barreiras e, principalmente, nos Sedimentos PósBarreiras, de idade eo/mesomiocena e pleistocena tardiaholocena, respectivamente. Os dados apresentados neste trabalho suportam deformação tectônica como um fator de grande relevância na distribuição das unidades sedimentares da Bacia Paraíba.

Palavras-chave: morfologia, sedimentologia, estratigrafia, cronologia, tectônica, Bacia Paraíba.

\section{REFERENCES}

Alheiros MM And Lima Filho MF. 1991. A Formação Barreiras. Revisão Geológica da Faixa Sedimentar Costeira de Pernambuco, Paraíba e Rio Grande do Norte. Est Geol, Ser B, Est Pesq 10: 77-88.

ARAI M. 2006. Revisão estratigráfica do Cretáceo Inferior das bacias interiores do Nordeste do Brasil. Rev Geoc USP 25: 7-15.

Arai M, Uesugui N, Rossetti DF and Góes AM. 1988. Considerações sobre a idade do Grupo Barreiras no nordeste do Estado do Pará. In: CONGRESSO BRASILEIRO DE GEOLOGIA, 35, Belém. Proceedings..., Belém, Soc Bras Geol 2: 738-752.

BARBOSA JA AND LIMA FILHO M. 2006. Aspectos estruturais e estratigráficos da faixa costeira Recife-Natal: observação em dados de poços. Bol Geoc Petr 14: 287-306.

Barbosa JA, Souza EM, Lima Filho M And Neumann VH. 2003. A estratigrafia da bacia Paraíba: uma reconsideração. Est Geol 13: 89-108.
BEURLEN K. 1967a. Estratigrafia da faixa sedimentar costeira Recife-João Pessoa. Bol Geol Univ Est São Paulo 16: 43-53.

BEURLEN K. 1967b. Paleontologia da faixa sedimentar costeira Recife-João Pessoa. Bol Geol Univ Est São Paulo 16: 73-79.

BEZERRA FHR, AMARO VE, VitA-FinZI C AND SAADI A. 2001. Pliocene-Quaternary fault control of sedimentation and coastal plain morphology in NE Brazil. J South Am Earth Sci 14: 61-75.

Bezerra FHR, Brito Neves BB, Correa ACB, BArReto AMF AND SUGUIO K. 2008. Late Pleistocene tectonicgeomorphological development within a passive margin: the Cariatá trough, northeastern Brazil. Geomorphology 97: 555-582.

BEZERRA FHR, FonsECA VP, VITA-FINZI C, LIMA FILHO FP AND SAADI A. 2005. Liquefaction-induced structures in Quaternary alluvial gravels and gravels sediments, NE Brazil. In: OBERMEIER SF (Ed), Paleoliquefaction and appraisal of seismic hazards. Eng Geol 76: 191-208.

BEZERRA FHR, TAKEYA MK, SOUSA MOL AND NASCIMENTO AF. 2007. Coseismic reactivation of the Samambaia fault. Tectonophysics 430: 27-39.

Bigarella JJ. 1975. The Barreiras Group in Northeastern Brazil. An Acad Bras Cienc 47: 365-393.

Brito NeVes BB, Albuquerque JPT, Coutinho JMV AND BEZERRAFHR. 2009. Novos dados geológicos e geofísicos para a caracaterização geométrica e estratigráfica da Subbacia de Alhandra (sudeste da Paraíba). Rev Geoc USP 9: 63-87.

Brito Neves BB, SANtos EJ AND VAN Schmus WR. 2000. Tectonic history of the Borborema Province, northeastern Brazil. In: CORDANI U, MILANI EJ, THOMAZ FILHO A AND CAMPOS DA (Eds), Tectonic evolution of South America: $31^{\text {st }}$ International Geological Congress, Rio de Janeiro, Brazil, p. 151-182.

CASTRO DL, BEZERRA FHR AND CASTELO BRANCO RMG. 2008. Geophysical evidence of crustal-heterogeneity control of fault growth in the Neocomian Iguatu basin, NE Brazil. J South Am Earth Sci 26: 271-285.

Córdoba VC, SÁ EFJ, Sousa DC ANd Antunes AF. 2008. Bacia de Pernambuco-Paraíba. Bol Geoc Petr 15: 391-403.

FERREIRA JM, BEZERRA FHR, SOUSA MOL, NASCIMENTO AF, SÁ JM AND FRANÇA GS. 2008. The role of Precambrian mylonitic belts and present-day stress field in the coseismic reactivation of the Pernambuco lineament, Brazil. Tectonophysics 456: 111-126.

FERREIRA JM, OLIVEIRA RT, TAKEYA MK AND ASSUMPÇÃO M. 1998. Superposition of local and regional stresses in NE Brazil: evidence from focal mechanisms around the Potiguar Basin. Geoph J Int 134: 341-355.

Furrier M, ARAÚJO ME AND MENESES LF. 2006. Geomorfologiae tectônica da Formação Barreiras no estado da Paraíba. Rev Geoc-USP 6: 61-70.

Leite FP, Oliveira MEB, ARAi M AND TRUCKEnBRodt W. 1997b. Palinoestratigrafia da Formação Pirabas e Grupo Barreiras, Mioceno do nordeste do estado do Pará, Brasil. Rev Univ Guarulhos (Geoc) 2: 141-147. 
Leite FPR, Oliveira MEB, OliveIra PE, SilvestreCAPELATO MS, ARAi M AND TRUCKENBROdT W. 1997a. Palinofloras miocenas da Formação Pirabas e Grupo Barreiras, na Região Bragantina, Estado do Pará, Brasil. Rev Univ Guarulhos (Geoc) 2: 128-140.

LIMA MG. 2008. A história do intemperismo na Província Borborema Oriental, nordeste do Brasil: implicações paleoclimáticas e tectônicas. Doctoral Thesis, Universidade Federal do Rio Grande do Norte, Natal, 251 p.

Mabesoone JM, CAMPos-Silva A AND BuERLEN K. 1972. Estratigrafia e origem do Grupo Barreiras em Pernambuco, Paraíba e Rio Grande do Norte. Rev Bras Geoc 2: 173-188.

MACEACHERn JA AND PEMBERTON SG. 1994. Ichnological aspects of incised-valley systems from the Viking Formation of the Western Canada sedimentary basin, Alberta, Canada. In: DALRYMPLE RW, BOYD R AND ZAITLIN BA (Eds), Incised-valley systems: origin and sedimentary sequences: Soc Sedim Geol Spec Publ 51, Tulsa, USA, p. 129-157.

MANGE MA, DEWEY JF AND WRIGHT DT. 2003. Heavy minerals solve structural and stratigraphic problems in Ordovician strata of the western Irish Caledonides. Geol Mag 140: $25-30$

Matos RMD. 1992. The Northeastern Brazilian rift systems. Tectonics 11: 766-791.

MORTON AC. 1985. Heavy minerals in provenance studies. In: ZUFFA GG (Ed), Provenance of arenites: Reidel, Dordrecht, The Netherlands, p. 249-277.

Morton AC AND Hallsworth C. 1994. Identifying provenance-specific features of detrital heavy mineral assemblages in sandstones. Sedim Geol 90: 241-256.

NETTO RG AND RossetTI DF. 2003. Ichnology and salinity fluctuations: a case study in the Early Miocene (Lower Barreiras Succession) of São Luís Basin, Maranhão, Brazil. Rev Bras Paleont 6: 5-18.

Nóbrega MA, SÁ JM, Bezerra FHR, HAdler Neto JC, Iunes PJ, Guedes S, Tello SAenz CA, HACKSPACHER PC AND LiMA FilHo FP. 2005. The use of apatite fission track thermochronology to constrain fault movement and sedimentary basin evolution in northeastern Brazil. Rad Meas 39: 627-633.

NOGUEIRA FC, BEZERRA FHR AND FUCK RA. 2010. Quaternary fault kinematics and chronology in intraplate northeastern Brazil. J Geod 49: 79-91.

Nogueira FCC, Bezerra FHR And CAstro DL. 2006. Deformação rúptil em depósitos da Formação Barreiras na porção leste da Bacia Potiguar. Rev Geoc USP 6: 51-59.

Pemberton SG, Maceachern JA AND Frey RW. 1992.Trace fossil facies models: environmental and allostratigraphic significance. In: WALKER RG AND JAMES N (Eds), Facies models: response to sea level change: Geol Assoc Can Newfoundland, Canada, p. 47-72.

Pemberton SG AND Wightman DM. 1992. Ichnological characteristics of brackish water deposits. In: PEMBERTON SG (Ed), Applications of ichnology to petroleum exploration-a core workshop: Soc Econ Paleont Mineral Spec Publ 17, Tulsa, USA, p. 141- 167.
ROBERTS HM AND DULLER GAT. 2004. Standardised growth curves for optical dating of sediment using multiple grain aliquots. Rad Measur 38: 241-252.

RosSETTI DF. 2000. Influence of low amplitude/high frequency relative sea-level changes in a wave-dominated estuary (Miocene), São Luís Basin, northern Brazil. Sedim Geol 133: 295-324.

RosSETTI DF. 2004. Paleosurfaces from northeastern Amazonia as a key for reconstructing paleolandscapes and understanding weathering products. Sedim Geol 169: 151-174.

RosSETTI DF. 2006. The role of tectonics on the preservation of estuarine valleys in areas with low accommodation rates: examples from Upper Cretaceous and Miocene successions in Northern Brazil. In: DALRYMPLE RW, LECKIE DA AND TILLMAN RW (Eds), Incised valley in time and space. Soc Econ Paleont Mineral Spec Publ 85, Tulsa, USA, p. 199-218.

RossetTI DF, BEZERRA FHR, GóES AM AND BRITO NEVES BBB. 2011. Sediment deformation in Miocene and post-Miocene strata, Northeastern Brazil: evidence for paleoseismicity in a passive margin. Sedim Geol 235: 172-187.

RosSETTI DF AND DoMinguez JML. In press. A Formação Barreiras. In: BARBOSA JSF, MASCARENHAS JF, GOMES, LCC AND DOMINGUEZ JML (Eds), Geologia da Bahia. Bahia, Comp Bah Pesq Miner.

Rossetti DF AND GóES AM. 2009. Marine influence in the Barreiras Formation, State of Alagoas, Northeastern Brazil. An Acad Bras Cienc 81: 741-755.

RossetTi DF, TRUCKENBRODT W AND GÓES AM. 1989. Estudo paleoambiental e estratigráfico dos sedimentos Barreiras e Pós-Barreiras na Região Bragantina, nordeste do Pará. Bol Mus Par Emílio Goeldi (Ser Cienc Terra) 1: 25-74.

SAADI A AND TORQUATO JR. 1992. Contribuição à Neotectônica do Estado do Ceará. Rev Geol 5: 5-38.

SHUSTER DL, FARLEY KA, SISTERSON JM AND BURNETT DS. 2004. Quantifying the diffusion kinetics and spatial distributions of radiogenic ${ }^{4} \mathrm{He}$ in minerals containing proton-induced ${ }^{3} \mathrm{He}$. Earth Planet Sci Lett 217: 19-32.

SHUSTER DL, VASCONCELOS PM, HeIM JÁ AND FARLEY KA. 2005. Weathering geochronology by (U-Th)/He dating of goethite. Geoch Cosmoch Act 69: 659-673.

TATUMi SH, Silva LP, Pires EL, Rossetti DF AND Góes AM. 2008. Datação de Sedimentos Pós-Barreiras no norte do Brasil: implicações paleogeográficas. Rev Bras Geoc 38: 514-524. 